\title{
Convergent evolution of two Silurian graptolites
}

\author{
Alfred C. Lenz and Michael J. Melchin \\ Acta Palaeontologica Polonica 53 (3), 2008: 449-460 doi:http://dx.doi.org/10.4202/app.2008.0307
}

The two graptolite species Cochlograptus veles (Telychian, Upper Llandovery) and Testograptus testis (lower Homerian, upper Wenlock) are remarkably and uniquely similar in being strongly ventrally and planispirally coiled and in demonstrating an abrupt deflection in the immediate post-sicular regions of their rhabdosomes. The two species, however, are separated by a relatively large biostratigraphic gap and a global mass extinction, and they differ morphologically in the proportion of thecal overlap, different angles of inclination of the interthecal septa, relative proportions of the widths occupied by the free metathecae, the position of the sharp dorsal flexure relative to the tip of the sicula, and the presence of a distinctive, keel-like structure on T. testis. It is suggested therefore, that in spite of the strong proximal morphological parallelism between the two species, their origin is best explained as a remarkable example of convergent evolution. It is suggested that $C$. veles perhaps evolved from some modified monograptid such as Stimulograptus, whereas the small Testograptus group may have derived from some monograptid such as Monograptus flemingii. Cladistic analysis fully supports the independent derivation the two species. If correct, this hypothesis supports the validity of separate generic names for the two species, despite the close and unique rhabdosomal similarities, including proximal metathecal form.

Key words: Graptoloidea, Monograptidae, taxonomic nomenclature, convergent evolution, pseudovirgula, Llandovery, Wenlock

Alfred C. Lenz [aclenz@uwo.ca], Department of Earth Sciences, University of Western Ontario, London, Ontario, N6A 5B7, Canada; Michael J. Melchin [mmelchin@stfx.ca], Department of Geology, St. Francis Xavier University, Antigonish, Nova Scotia, B2G 2W5, Canada.

This is an open-access article distributed under the terms of the Creative Commons Attribution License (for details please see creativecommons.org), which permits unrestricted use, distribution, and reproduction in any medium, provided the original author and source are credited. 
Fof Full text $(708.8 \mathrm{kB})$ 